The $6^{\text {th }}$ Conf. of SSFOP “Sustainable Development of Ornamental, Medicinal and Aromatic

Plants Scope”, Cairo, Egypt, 1/3/2020

Scientific J. Flowers \& Ornamental Plants

www.ssfop.com/journal

ISSN: 2356-7864

doi: $10.21608 /$ sjfop.2020.91398

\title{
ORNAMENTAL PLANTS AND CLIMATE CHANGE: CARBON DIOXIDE AND ATMOSPHERIC TEMPERATURE
}

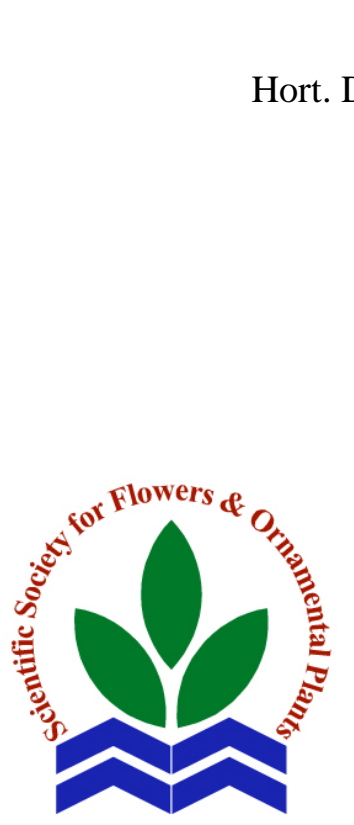

Scientific J. Flowers \& Ornamental Plants, 7(1):71-76 (2020).

Received:

28/1/2020

Accepted:

$16 / 2 / 2020$

\author{
E.M. Koriesh
}

ABSTRACT: Virtually, one usually experiences a significant coolness around and under trees in comparison to open sunshine, with qualitative variations. This study was conducted to investigate the effect of irrigation with saline water (8000 and $16000 \mathrm{ppm})$ on some trees and their effect on transpiration rates, and the impact of these trees on reducing the atmospheric temperature and therefore their impact on climate change. The trees under study were used in the study: Bauhinia variegata, Cassia fistula, Cassia nodosa, Eucalyptus camaldulensis, Ficus retusa and Khaya senegalensis. In general, results indicated that, the atmosphere was cooler around Cassia fistula by reduction of atmospheric temperature by $6.5{ }^{\circ} \mathrm{C}$ (also, it produces odorous flowers) followed by Eucalyptus camaldulensis $\left(5.3{ }^{\circ} \mathrm{C}\right)$. Reduction of temperature was correlated with high transpiration rate after irrigation with saline water after 2, 4 and 8 days of irrigation. It can be concluded that, using of saline water in irrigation of ornamental trees is efficient to induce the cooling effect in our gardens. Also, results showed the superiority of some trees in their efficiency in absorbing $\mathrm{CO}_{2}$ and were in the following order: Ficus religiosa (87.65); Bauhinia variegata (83.76); Cassia nodosa (81.53); Eucalyptus camaldulensis (80.15); Khaya senegalensis (79.04); Chorisia speciosa (73.29); Cassia fistula (72.54); Bombax malabaricum (72.34); Erythrina variegata (71.82); Ficus retusa (71.33); Ficus benghalensis (67.20) and Tipuana speciosa (65.99).

Key words: saline water, carbon dioxide, transpiration, cooling effects, Bauhinia variegata, Cassia fistula, Cassia nodosa, Eucalyptus camaldulensis, Ficus retusa and Khaya senegalensis.

\section{INTRODUCTION}

The cooling effect of a tree is a result of physiological tasks of the tree. It depends on tree characters including shape, leaves type and number, besides, tree physiological functioning such as rate of transpiration. The cooling produced by trees varies with species due to variation in several anatomical, structural and physiological attributes of the species (Caemmerer and Baker, 2007). Therefore, cultivation of trees is usually practiced for controlling the urban environment including cooling and air pollution abatement (Nowak, 2002).

Working with some tree species, Gupta et al. (2018) disclosed temperature reduction under shades of trees from $0.64{ }^{\circ} \mathrm{C}$ to 2.52 ${ }^{\circ} \mathrm{C}$ whereas Abdel-Aziz (2014) reported cooling under tree shades from $1{ }^{\circ} \mathrm{C}$ to $5{ }^{\circ} \mathrm{C}$. They added that transpiration is one of the most significant physiological functions achieved by plants, which affects cooling effect of tree. 


\section{E.M. Koriesh}

When solar energy impinges on the leaf, water emerges from its surface through transpiration taking the latent heat to convert it into water vapor. This leads to a rise in humidity of the atmosphere and reduction in temperature of the leaf. To evaporate 1 gram of water requires 600 calories (Jones, 2007). To encourage research on identification of ecologically more valuable species is of utmost importance to face the present challenges of global warming.

Urban trees do not have the suitable share of conventional water for irrigation, needing the use of high saline water from wells or blended with fresh water. Under salt stress results of Hasanuzzaman et al. (2017) displayed that transpiration was higher in old leaves than in the young one leaves. Ben-Gal et al. (2008) said that increased application of saline irrigation water led to increasing transpiration. Salt tolerant plants transpired more water than the sensitive variety under normal growth conditions. In contrary, Schröder et al. (2014) concluded that salinity causes osmotic imbalance, reduced water uptake and transpiration.

Thus, the present study was conducted to determine the transpiration rates and cooling effects of some urban trees at Ismailia when using fresh or saline water.

\section{MATERIALS AND METHODS}

This experiment was carried out at Suez Canal Region, through June, 2018 (average temperature between 34.8 and $19.5{ }^{\circ} \mathrm{C}$ and relative humidity $44 \%$ (Climate in Ismailia, Egypt, 2018), to evaluate the effect of exposure duration for some trees to saline irrigation-water on transpiration rate. Also, the effects of transpiration rate on cooling effect $\left({ }^{\circ} \mathrm{C}\right)$ in the surrounding area for each tree.

\section{Plant materials}

Five Fresh branches (in 5 replicates) of the following trees: Bauhinia variegata, Cassia fistula, Cassia nodosa, Eucalyptus camaldulensis, Ficus retusa, Ficus religiosa, Chorisia speciosa, Erythrina variegata,
Tipuana speciose and Khaya senegalensis were used. This experiment was conducted during 2018 summer season. Transpiration was calculated after Royal Society of Biology (2008).

\section{Salinity treatments:}

Sodium chloride solution at concentrations of 0,8000 and $16000 \mathrm{ppm}$ were used. Transpiration rate per $1000 \mathrm{~cm}^{2}$ green leaves after 2, 4 and 8 days was measured (Pawar, 2017).

\section{Calculation the cooling effects:}

- An estimate of the average tree size and average leaf area was carried out according to NParks Flora \& Fauna Web (2019).

- Average number of leaves according to Czernia (2019).

- Transpiration rate according to Pawar (2017)

- Number of calories needed for evaporation of $1 \mathrm{~g}$ of water (about 600 calories) according to Behan (1992).

- Conversion of caloric value to C degrees according to Conversion of Measurement Units (2019).

\section{Carbon dioxide absorption and calculations:}

A suitable part was taken from each plant and placed in a glass container inside a handmade growth room with sufficient lighting. Carbon dioxide was injected from a liquid gas cylinder and measured. After 5, 10 and 15 minutes from the injection, the carbon dioxide concentration was measured. Leaves area of the plant part was calculated, and the amount of carbon dioxide absorbed was calculated per $1000 \mathrm{~cm}^{2}$ of the leafy area for each plant. Carbon dioxide was measured by Indoor Air Quality Carbon Dioxide Meter Model 77535, Gainexpress Company.

\section{Statistical Analysis:}

All data were statistically analyzed as randomized complete blocks design (Bailey, 2008); using the MSTAT-C statistical package (Hasanuzzaman, 2008) and means 
were compared by Duncan's multiple range test $\mathrm{P} \leq 0.05$ (Duncan, 1955).

\section{RESULTS AND DISCUSSIONS}

\section{Effect of salinity levels on transpiration} rate:

Table (1) shows that the use of saline water increased the transpiration rate in all trees under study. These results are consistent with the findings of Ben-Gal et al. (2008). It is evident in the same Figure that both Eucalyptus and Cassia fistula were the most transpiration plants at all treatments. In this respect, Taiz and Zeiger (2012) found that the plants differ in the parameters of transpiration from each other.

The effect of trees on reducing the atmospheric temperature:

The results presented in Table (2) refer that Cassia fistula trees were the highest reducer of atmospheric temperature (6.517 ${ }^{\circ} \mathrm{C}$ ) followed by Eucalyptus trees $\left(5.343^{\circ} \mathrm{C}\right)$. These findings among different trees may be related with the different size of the area occupied by the tree, number of leaves per tree and their transpiration rates.

Table (3) shows that trees differ in their efficiency of absorption or sequestration of carbon dioxide per $1,000 \mathrm{~cm}^{2}$ plant leaves.

Table 1. Effect of saline irrigation-water levels on transpiration $\left(\mathrm{cm}^{3}\right)$ after 2,4 and 8 days of irrigation of some ornamental trees.

\begin{tabular}{lcccc}
\hline Plants & $\begin{array}{c}\text { Salinity } \\
\text { level } \\
\text { (ppm) }\end{array}$ & $\begin{array}{c}\text { Transpiration after } \mathbf{2} \\
\text { days for } \mathbf{1 0 0 0} \mathbf{~ c m}^{2}\end{array}$ & $\begin{array}{c}\text { Transpiration after } \mathbf{4} \\
\text { days for } \mathbf{1 0 0 0} \mathbf{~ c m}^{2}\end{array}$ & $\begin{array}{c}\text { Transpiration after } \mathbf{8} \\
\text { days for } \mathbf{1 0 0 0} \mathbf{~ c m}^{2}\end{array}$ \\
\hline Bauhinia variegata & $\mathbf{0}$ & $11.0 \mathrm{~d}$ & $25.5 \mathrm{c}$ & $22.3 \mathrm{~h}$ \\
& $\mathbf{8 0 0 0}$ & $9.1 \mathrm{de}$ & $25.5 \mathrm{c}$ & $23.8 \mathrm{~h}$ \\
Cassia fistula & $\mathbf{1 6 0 0 0}$ & $5.6 \mathrm{ef}$ & $16.0 \mathrm{~cd}$ & $23.4 \mathrm{~h}$ \\
& $\mathbf{0}$ & $29.2 \mathrm{~b}$ & $55.6 \mathrm{~b}$ & $29.0 \mathrm{gh}$ \\
& $\mathbf{8 0 0 0}$ & $23.6 \mathrm{c}$ & $45.8 \mathrm{~b}$ & $34.3 \mathrm{e}-\mathrm{h}$ \\
Cassia nodosa & $\mathbf{1 6 0 0 0}$ & $42.1 \mathrm{a}$ & $92.2 \mathrm{a}$ & $30.4 \mathrm{f}-\mathrm{h}$ \\
& $\mathbf{0}$ & $7.4 \mathrm{~d}-\mathrm{f}$ & $15.7 \mathrm{~cd}$ & $39.1 \mathrm{~d}-\mathrm{g}$ \\
& $\mathbf{8 0 0 0}$ & $7.9 \mathrm{~d}-\mathrm{f}$ & $15.6 \mathrm{~cd}$ & $41.6 \mathrm{~d}-\mathrm{g}$ \\
Eucalyptus & $\mathbf{1 6 0 0 0}$ & $7.9 \mathrm{~d}-\mathrm{f}$ & $16.6 \mathrm{~cd}$ & $40.2 \mathrm{~d}-\mathrm{g}$ \\
& $\mathbf{0}$ & $25.2 \mathrm{c}$ & $48.3 \mathrm{~b}$ & $44.6 \mathrm{~d}-\mathrm{f}$ \\
& $\mathbf{8 0 0 0}$ & $31.4 \mathrm{~b}$ & $54.4 \mathrm{~b}$ & $52.1 \mathrm{~d}$ \\
Ficus retusa & $\mathbf{1 6 0 0 0}$ & $26.6 \mathrm{bc}$ & $47.7 \mathrm{~b}$ & $47.9 \mathrm{de}$ \\
& $\mathbf{0}$ & $5.9 \mathrm{ef}$ & $15.3 \mathrm{~d}$ & $52.9 \mathrm{~cd}$ \\
& $\mathbf{8 0 0 0}$ & $4.6 \mathrm{f}$ & $10.7 \mathrm{~d}$ & $85.7 \mathrm{~b}$ \\
Khaya senegalensis & $\mathbf{1 6 0 0 0}$ & $8.6 \mathrm{de}$ & $16.2 \mathrm{~cd}$ & $66.7 \mathrm{c}$ \\
& $\mathbf{0}$ & $9.1 \mathrm{de}$ & $19.5 \mathrm{~cd}$ & $106.6 \mathrm{a}$ \\
& $\mathbf{8 0 0 0}$ & $7.3 \mathrm{~d}-\mathrm{f}$ & $14.3 \mathrm{~d}$ & $144.9 \mathrm{a}$ \\
& $\mathbf{1 6 0 0 0}$ & $9.0 \mathrm{de}$ & $16.7 \mathrm{~cd}$ & $127.8 \mathrm{a}$ \\
\hline
\end{tabular}

Means within a column having the same letter are not significantly different according to Duncan's

Table 2. Effect of trees on reduction of the atmospheric temperature.

\begin{tabular}{lc}
\hline Plants & Cooling effect ${ }^{\circ} \mathbf{C}$ (based on transpiration of control treatments) \\
\hline Bauhinia variegata & 1.533 \\
Cassia fistula & 6.517 \\
Cassia nodosa & 4.527 \\
Eucalyptus camaldulensis & 5.343 \\
Ficus retusa & 4.123 \\
Khaya senegalensis & 3.896 \\
\hline
\end{tabular}


Table 3. $\mathrm{CO}_{2}$ absorption efficiency per $1000 \mathrm{~cm}^{2}$ of tree leaves, arranged descendingly.

\begin{tabular}{lccc}
\hline Plants & $\begin{array}{c}\text { Efficiency of reducing } \\
\text { \% after } \mathbf{5 ~ m i n}\end{array}$ & $\begin{array}{c}\mathbf{O}_{2} \text { Efficiency of reducing } \mathbf{C O}_{2} \text { Efficiency of reducing } \mathbf{C O}_{2} \\
\text { \% after 10 min }\end{array}$ & $\begin{array}{c}\text { \% } \\
\text { after } \mathbf{~ m i n ~}\end{array}$ \\
\hline Ficus religiosa & 87.6 & 92.1 & 92.6 \\
Bauhinia variegata & 83.7 & 89.0 & 94.3 \\
Cassia nodosa & 81.5 & 85.2 & 88.7 \\
Eucalyptus camaldulensis & 80.2 & 85.7 & 91.1 \\
khaya senegalensis & 79.0 & 89.3 & 92.2 \\
Chorisia speciosa & 73.3 & 90.3 & 95.9 \\
Cassia fistula & 72.5 & 81.8 & 91.1 \\
Bombax malabaricum & 72.3 & 82.7 & 93.2 \\
Erythrina variegaa & 71.8 & 88.1 & 89.8 \\
Ficus retusa & 71.3 & 78.9 & 86.5 \\
Ficus benghalensis & 67.2 & 85.7 & 87.5 \\
Tipuana speciose & 65.9 & 84.7 & 86.3 \\
\hline
\end{tabular}

Also, Ficus religiosa trees were the most efficient for the unit of area of leaves, followed by Bauhinia variegata. On the other hand, Ficus retusa trees, which are grown in large quantities in the Egyptian environment, are not the most efficient, and this requires a review of their cultivation in the Egyptian environment in general or in Ismailia in particular. The difference in trees' absorption of carbon dioxide corresponds to the results of Nowak (2002), Nowak et al. (2013) and Nowak et al. (2014).

\section{Conclusion:}

Saline water can be used for irrigation of the ornamental trees in gardens to reduce the ambient temperature and heat islands. Saline water may increase the transpiration rate of trees. Cassia fistula and Eucalyptus camaldulensis are suitable trees in cooling effect of Ismailia Governorate gardens.

\section{REFERENCES}

Abdel-Aziz, D.M. (2014). Effects of tree shading on building energy consumption. Journal of Architectural Engineering Technology, 3, 135. https://doi.org /10.4172/2168-9717.1000135

Bailey, R.A. (2008). Design of Comparative Experiments. Cambridge University Press. http://assets.cambridge.org/ 97805218/65067/frontmatter/978052186 5067_frontmatter.pdf

Behan, M. (1992). Lessons in soil - plant water relationships. Pakistan Forest Institute. Peshawar. http://www.esalq. usp.br/lepse/imgs/conteudo/Soil-PlantWater-Relationships-by-Mark-Behan-1992--1.pdf

Ben-Gal, A., Ityel, E.; Dudley, L.; Cohen, S.; Yermiyahu, U.; Presnov, E. and Shani, U. (2008). Effect of irrigation water salinity on transpiration and on leaching requirements: A case study for bell peppers. Agricultural Water Management, 95(5):587-597.

Caemmerer, S. and Baker, N. (2007). The Biology of Transpiration. From Guard Cells to Globe. Plant physiology. The American Society of Plant Biologists.

Climate in Ismailia, Egypt (2018). https://weather-and-climate.com/averagemonthly-Rainfall-Temperature-Sunshine, ismailia-ismailia-eg,Egypt

Conversion of Measurement Units (2019). Convert calories to Celsius heat unit. https://www.convertunits.com/from/calor ies/to/celsius+heat+unit

Czernia, D. (2019). Tree leaves calculator. Omni Calculator. https://www.omni calculator.com/other/tree-leaves 
Duncan, D.B. (1955). Multiple range and multiple $\mathrm{F}$ test. Journal of Biometrics, 11:1-42.

Gupta, S.K.; Ram, J. and Singh, H. (2018). Comparative study of transpiration in cooling effect of tree species in the atmosphere. Journal of Geoscience and Environment Protection, 6:151-166.

Hasanuzzaman, M. (2008). Data analysis with MSTAT-C. https://hasanuzzaman. weebly.com/uploads/9/3/4/0/934025/data _analysis_with_mstat.pdf

Hasanuzzaman, M.; Davies, N.W.; Shabala, L.; Zhou, M. and Brodribb, T. (2017). Residual transpiration as a component of salinity stress tolerance mechanism: A case study for barley. BMC Plant Biology, 17(1):107.

Jones, H.G. (2007). Monitoring plant and soil water status: established and novel methods revisited and their relevance to studies of drought tolerance. J. of Exp. Bot., Vol.58: 119-130.

Nowak, D.J. (2002). The effects of urban trees on air quality. USDA Forest Service. https://www.nrs.fs.fed.us/units/ urban/local-resources/downloads/Tree_ Air_Qual.pdf

Nowak, D.J., Hirabayashi, S.; Ellis, E. and Greenfield, E. (2014). Tree and forest effects on air quality and human health in the United States. Environ. Pollut., 193:119-129.

Nowak, D.J.; Greenfield, E.J.; Hoehn, R. and Lapoint, E. (2013). Carbon storage and sequestration by trees in urban and community areas of the United States. Environ. Pollut. 178:229-236.

NParks Flora \& Fauna Web (2019). https://www.nparks.gov.sg/florafaunawe b/flora/1/5/1593\

Pawar, K. (2017). Measuring transpiration with a simple low-cost, single-leaf potometer. The American Biology Teacher, 79(3):238-240.

Royal Society of Biology (2008). Practical Biology. Estimating the rate of transpiration from a plant cutting. https://pbiol.rsb.org.uk/exchange-ofmaterials/transpiration-in-plants.

Schröder, N.; Lazarovitch, N.; Vanderborght, J.; Vereecken, H. and Javaux, M. (2014). Linking transpiration reduction to rhizosphere salinity using a 3D coupled soil-plant model. Plant and Soil., 377:277-293.

Taiz, L. and Zeiger, E. (2012). Plant Physiology, Chapter 4, Water Balance of Plants. Fifth Edition, Sinauer Associates Inc., Massachusetts U.S.A., pp. 85-102.

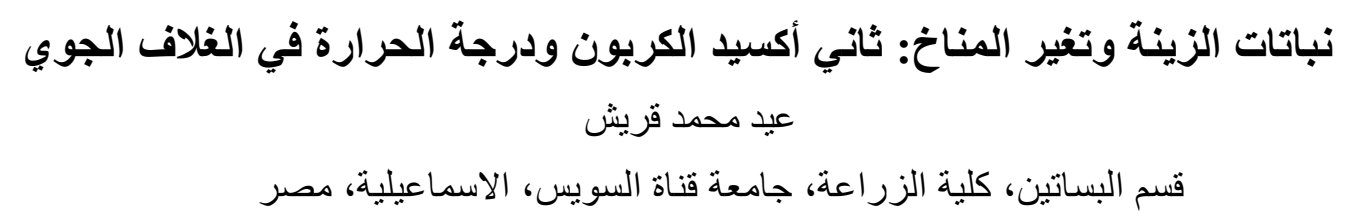

يعتبر النتح في الأشجار أحد الوسائل التي تستخدمها النباتات لتنظيم درجة الحر ارة في الأوراق، و وعادة ما

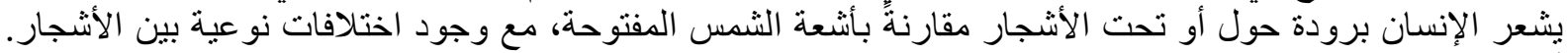

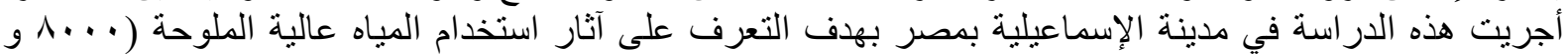

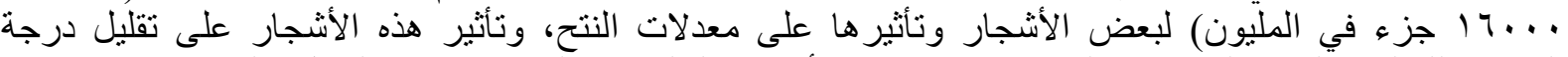

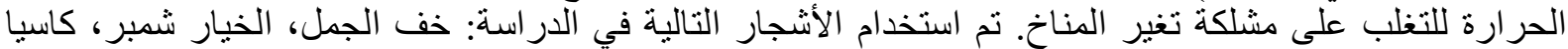

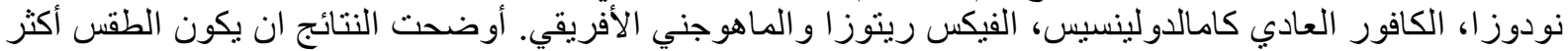

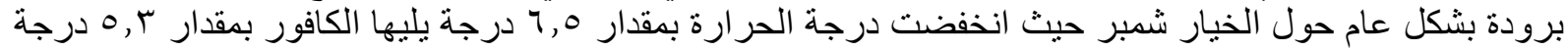

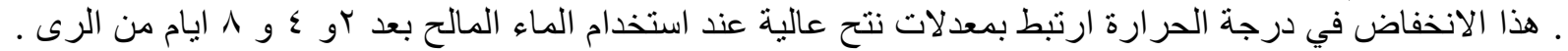




\section{E.M. Koriesh}

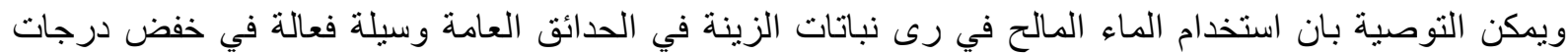

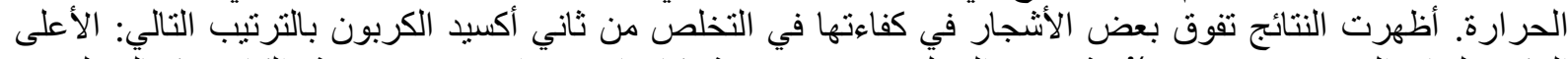

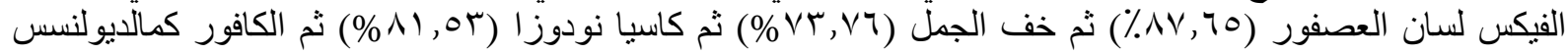

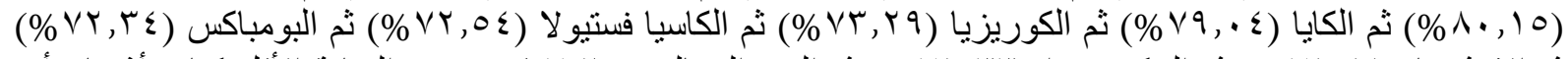

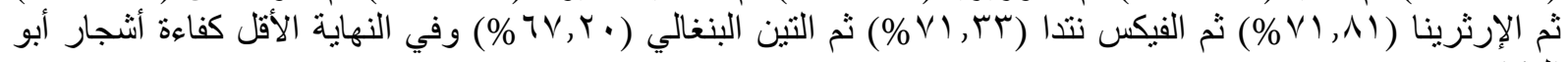

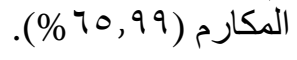

